\title{
Minority Language Rights: What Matters? A Comparison of Belgium and Canada
}

\author{
Tamara Levy, Concordia University \\ Public Policy and Public Administration, M.A. Candidate
}

In federal societies, intergovernmental relations are necessarily a part of political life. But, as a student of intergovernmental relations (IGR), I want to understand, how much do intergovernmental relations really matter to particular policy outcomes? In order to assess this question, I have undertaken a study of minority language rights policies in two federal societies, Belgium and Canada (the Countries). In these circumstances, the above question is refined and can instead be stated as follows: what factors influence the content of minority language policies in the Countries?

Again, coming from the perspective of an IGR student, I expected the answer to be that intergovernmental relations influence the content of minority language rights. However, my initial expectations have been disproved and I have discovered that minority language policies in the Countries are more susceptible to normative influences than institutional ones. More exactly, in this essay, I will argue that the dominant variables affecting the content of minority language rights in the Countries are the relative situation of language groups and the values underlying political culture (the Dominant Variables).

Both my above-stated research question and hypothesis are not matters of simple assertion. Instead, my study is undertaken against a rich academic background, as the topic of minority language rights has been vigorously studied, and theories regarding influences and approaches abound. In my view, the interest in this subject is unsurprising 
given the somewhat precarious and evolving nature of federal societies and the role which minority language groups can play in "making or breaking" a federation. The topic is also of interest because many federal states must consider the accommodation of minority language groups, and comparative studies generate much-needed policy approaches, and assess the applicability of these approaches to different federal scenarios.

Since the issue chosen for study is a relatively complicated and considered one, how do I intend to support my contention that the Dominant Variables do dominate the outcomes in this policy sector? Basically, I propose that the primary influence of the Dominant Variables can be deduced from the following factors: the reflection of the variables in the policy outcomes themselves; and, the evolution of the policy outcomes in direct consonance with the evolution of the variables themselves. Moreover, while the variables of primary importance are the same as between the Countries, the way in which the Dominant Variables manifest themselves is different, and this difference explains the divergent policy outcomes in the Countries.

While I draw on the existing literature to build these arguments, the scholars of Belgian and Canadian language policies who precede me point to the influence of either or both of the Dominant Variables, though fail to question the influence of the variables from the "macro" point of view of "what matters to policy outcomes" and fail to link the influence of the variables back to the content of the policy. I intend to address this gap and complete the analysis by reviewing both the influence of the Dominant Variables and their specific effect on policy outcomes.

In terms of the structure of this essay, I proceed in two parts. In the first part, I provide important background information concerning both the framework of federalism and the minority language policy outcomes in both of the Countries. In the second part, I 
propose which variables affected the divergent policy outcomes in the federal societies under review. In this section I undertake the analysis described briefly above, and argue why the Dominant Variables can be asserted as dominant and how they have been integrated into policy outcomes.

Before undertaking any of this analysis however, I begin with a brief discussion of my methodology and the basis of comparison of the Countries.

\section{APPROACH}

\section{A. Methodology}

In terms of methodology I propose to proceed in my comparative analysis as follows:

- $\quad$ Define the Framework of Federalism: In order to define the framework of federalism at issue in the two federations, I review two indicators, the constitutional arrangements and the institutional arrangements. As to the former, I identify which levels of governments have which powers in the area of minority language rights. As to the latter, I determine what institutional arrangements (formal and informal) are at work between levels of government concerning this policy sector.

- Define the Policy Outcome: In order to define the policy outcome, I delineate the scope of the policy sector, and determine which aspect of "minority language rights" I will review. I intend to define minority language rights by reference to two indicators: language of government services and language of (elementary/secondary) educational instruction. Having delimited the policy sector itself, I then define policy outcomes in the Countries by reference to these two indicators.

- Explain the Convergent and/or Divergent Policy Outcomes:

- In this section, I determine which factors primarily affect the policy outcomes and argue how I am able to assess their primary influence. I propose that the Dominant Variables were influential in the Countries, though towards different policy outcomes.

- I define the Dominant Variables as follows: relative situation of language groups refers to the numerical, economic and social importance of the language group, by reference to other language groups in society; political culture is the commitment to equality between language groups. ${ }^{1}$

\footnotetext{
${ }^{1}$ Of course there are other aspects to political culture which influence this policy sector, such as a commitment to national unity and a pattern of compromise. However, given the relative brevity of this essay, I can not explore all of these values, and instead have chosen what appears to be the most significant value, a commitment to equality, and explored only it. However, again, these other values are important and would deserve discussion in a longer paper.
} 
- While other variables certainly played a secondary role (such as the judiciary, civil society and political actors) given the relative brevity of this paper, I will not explore these variables of secondary influence. Instead, I will restrict my analysis to the two variables which I assert played a dominant role.

- I assess the influence of the Dominant Variables by evaluating how the variables are reflected within the policy outcomes and by evaluating how changes in the variables engendered changes in policy.

Having proposed the above methodology, I should address why I chose the Countries as my case studies, as well as my basis for comparison between the two.

\section{B. Basis for Comparison}

For this study, I sought similar federal countries so that the study could produce a reasoned analysis of what causal factors affected policy outcomes, and how those causal factors manifested themselves, amongst similar federations.

Of course, no two countries are the same; however, both Canada and Belgium are to some extent more similar than many. For example, both countries contain medium/small sized populations, a majority/minorities division along linguistic lines and a federal structure. Both countries are also relatively wealthy and have well-established democracies. Of course, there are many dissimilarities, such as the age of the federations and the geographic situation of the Countries. However, the similarities are significant and perfect matches can not be found. Thus, in this study, I should be able to assess, with some assuredness, what the causal factors at issue in this policy area are, and conclude that divergent (or convergent) policy outcomes are due to the particular manifestation of these causal factors in the Countries rather than due to the radically distinct situations of the Countries themselves. 


\section{PART I: BACKGROUND}

\section{A. Framework of Federalism: Constitutional Considerations}

\section{BELGI UM}

Concerning language, the Belgian constitution divides power between levels of governments and sets out important linguistic divisions and responsibilities within Belgian society and government.

As to the division of powers, the community level of government has primacy in language issues. More exactly, beginning with the 1970 constitutional reforms, responsibility for "cultural affairs" was devolved from the federal to the community level of government. ${ }^{2}$ Cultural affairs were later defined to include language as well as nearly all aspects of education. ${ }^{3}$

The federal government has limited powers respecting language rights. In terms of education, the federal government retains responsibility for general norms (such as the qualification and retirement age of teachers) only. In terms of government services, the federal government apparently lacks specific constitutional jurisdiction, although the parameters of its obligations are set out in statute (described below). ${ }^{4}$

In terms of imposing linguistic divisions and responsibilities, the constitution recognizes 3 geographic regions (Walloon, Flanders and Brussels-Capital) and three cultural communities (French, Flemish and German). ${ }^{5}$ The communities are granted full

\footnotetext{
${ }^{2}$ M. Jaumain, "Some Features of Cultural Policies Applied in Belgium, Particularly in the French-Speaking Community,” Journal of Arts Management, Law, and Society Vol. 27, No. 3 (Fall 1997) pp. 205-225 at 208.

${ }^{3}$ Id., at 209.

${ }^{4}$ K.D. McRae, Conflict and Compromise in Multilingual Societies (Waterloo: Wilfred Laurier Press, 1986) at 161-9.

${ }^{5}$ Articles 2 and 3 of the Belgian Constitution. The regions (Flanders, Walloon and Brussels-Capital) are territorially defined, while the communities (Flemish, French and German) are defined according to language and culture. But these communities also rest largely on a territorial basis: the authority of the Flemish community extends over Flanders plus the Flemish speaking population of Brussels, while the authority of the French community extends over Walloon (minus its German speaking communes) plus the
} 
legislative power over specified areas (as described above). The Communities'

jurisdiction extends to their respective language regions, and to the French and Flemish speakers of the Brussels region respectively. The constitution guarantees linguistic parity between French and Flemish ministers in the national cabinet. ${ }^{6}$

\section{CANADA}

The Canadian constitution also both divides power and defines certain linguistic rights.

As to the division of powers, the constitution ${ }^{7}$ does not specifically assign language to either level of government. Accordingly, a law prescribing the use of language is characterized as a law in relation to the institutions or activities that the enactment covers, rather than in relation to language. ${ }^{8}$

As to rights, the constitution sets out specific language rights. The Constitution Act, 1867 (C.A. 1867) contains only one provision of interest to our discussion. Specifically, it provides that the provincial legislature can make laws in relation to education. Flowing from this right, the province has the power to delineate the language of instruction in schools. However, Section 93 prohibits a legislature from prejudicially affecting rights or privileges respecting denominational schools existing by law at the time of confederation in $1867 .{ }^{9}$ Thus, if a language of instruction was a right or privilege

French speaking population of Brussels. While the Walloon region and French community each have their own government, the Flemish region and community are under a single combined council.

${ }^{6}$ J. Fitzmaurice, The Politics of Belgium: A Unique Federalism (London: Westview Press, 1996) at 162 at 150.

${ }^{7}$ The Canadian Constitution is essentially comprised of the Constitution Act, 1867 (U.K.), R.S.C. 1985, Appendix II, No. 5 (C.A. 1867) and the Constitution Act, 1982, U.K. Stats. 1982, c. 11, Appendix II (C.A. 1982). The C.A. 1867 is most remarkable for its division of power provisions (Sections 91 and 92) whereas the C.A. 1982 is most remarkable for its Charter of Rights and Freedoms (the Charter).

${ }^{8}$ Both levels of government have used this "constitutional vacuum” to institute laws dealing specifically with language. For example, in Jones v. Attorney General of New Brunswick, [1975] 2 S.C.R. 182, the Supreme Court of Canada (S.C.C.) upheld the federal Official Languages Act on the basis of the "peace order and good government” clause. Moreover, in Devine v. Quebec, [1988] 2 S.C.R. 790, the S.C.C. upheld portions of Quebec's Charter of the French Language on the basis of Section 92(13). Please see P.W. Hogg, Constitutional Law of Canada, vols. 1\&2, $4^{\text {th }}$ ed. (loose leaf) (Scarborough: Carswell, 1997- ) at Section 53.2.

${ }^{9}$ Section 93 applies only to Ontario, Quebec, New Brunswick, Nova Scotia, British Columbia and PEI. Counterparts are found in the statutes which constituted Manitoba, Alberta, Saskatchewan and 
of a denomination school in a province at confederation, the province is prevented from compelling the denominational school to instruct in a different language.

The Consitution Act, 1982 (C.A. 1982) contains a more elaborate set of language rights touching on the language of the legislature, government services and education. In terms of government services, sections 16 and 20 set out the relevant obligations. According to Section 16, English and French are the official languages of Canada and New Brunswick. According to Section 20, the (federal and New Brunswick) governments are obliged to provide bilingual services to the public. ${ }^{10}$ The other nine provinces of Canada have not undertaken any constitutional obligation to provide government services in both official languages, although as discussed below, some choose to do so.

In terms of education, Section 23 of the C.A. 1982 protects minority language education rights. In essence, 3 categories of parents are entitled to “qualified” minority language education rights for their children. The 3 categories are: parents whose mother tongue is in the minority (Section $23(1)(a)) ;{ }^{11}$ parents whose language of primary school instruction in Canada is in the minority (Section 23(1)(b)); and, parents who have or had another child enrolled in a minority language of instruction in Canada (Section 23(2)). These rights are all subject to the "where numbers warrant” qualification of Section 23(3)

Newfoundland. Quebec and Newfoundland have since undertaken a constitutional amendment and created language school boards. For a complete discussion, please see Hogg, supra, note 7 at Section 53.8(b).

${ }^{10}$ C.A. 1982, at Sections 16 and 20. Specifically, the federal obligation attaches to any head or central office of an institution of Parliament or the Government of Canada. It further attaches to any other office of the Government of Canada where either there is significant demand for bilingual services from that office; or, due to the "nature of the office" it is "reasonable" that bilingual services be provided by that office. The New Brunswick obligation is unqualified, and attaches to "any office of an institution of the Legislature or Government of New Brunswick."

${ }^{11}$ As per Section 59 of the C.A. 1982, Section 23(1)(a) does not apply to Quebec until its Legislative Assembly decides to adopt it. The result is that English speaking parents in Quebec have no right to send their children to English speaking schools, unless they fit into the second or third category of parents recognized by s. 23. 
which has been interpreted as providing a "sliding scale of entitlement” based on the number of children whose parents qualify. ${ }^{12}$

Having considered the constitutional background to the policy outcomes in the minority language sector, it is equally important to consider the institutional background.

\section{B. Framework of Federalism: Institutional Considerations}

Neither Belgium nor Canada has highly-developed institutions of intergovernmental relations relating to minority language rights.

\section{BELGI UM}

Belgium has certain institutions representing both intra- and inter-state federalism concerning minority language rights. As to intra-state federalism, the Belgian Senate was intended to be a regional body, with a portion of the senators directly elected, and another portion elected from the ranks of the communities. ${ }^{13}$ In addition to the parity requirement for federal cabinet, the executive requires overall legislative support and the consent of a majority of legislators within their linguistic groups. The executive also decides by consensus, giving French and Dutch speakers a mutual veto-right. Finally, any constitutional amendment or legislative enactment touching upon regional issues must be approved by two-thirds of the MPs in the federal lower house and senate, including a majority of each of the linguistic groups (in both houses). ${ }^{14}$

As to inter-state federalism, the constitution contains an “alarm bell” procedure which initiates a Conciliation Committee. ${ }^{15}$ An assembly pulls an "alarm bell” when it perceives that the initiative of another assembly could cause it serious harm. The

\footnotetext{
${ }^{12}$ Mahe v. Alberta, [1990] 1 S.C.R. 342 at 366.

${ }^{13}$ Senators are elected from the Communities as follows: 10 Flemish, 10 French, 1 German. The other two classes of Senators are “co-opted” and royal princes.

${ }^{14}$ W. Swenden, “Assymetric Federalism and Coalition-Making in Belgium” Publius Vol. 32, No. 3

(Summer 2002) pp. 67-87 at 76.

${ }^{15} \mathrm{Id}$., at 76-7.
} 
Conciliation Committee then tries to resolve the impasse. The committee is itself a model of intergovernmental co-ordination, as its members include the Prime Minister, the leaders of the French and Flemish Communities and the regions. A small secretariat exists to support the work of the conciliation committees, and has extended its work to inter-ministerial conferences, of which there are now 15, including education. ${ }^{16}$

\section{CANADA}

The intergovernmental structure concerning minority language rights in Canada is also relatively under-developed. In terms of intra-state federalism, the Senate of Canada, a body intended to (in small part) represent the regions in the Parliament of Canada, has a Committee on Official Languages with a mandate to study matters relating to official languages generally. ${ }^{17}$ The Supreme Court of Canada also contains an element of intrastate federalism with its pattern of regional representation. Specifically, since 1949, three judges on the court are from Quebec, three from Ontario, two from the Western provinces and one from the Atlantic. The Chief Justice of the court has usually alternated between Francophone and Anglophone. ${ }^{18}$

In terms of inter-state federalism, there is both a formal and informal aspect to the institutional structures. As to formal, the Ministerial Conference on Francophone Affairs consists of the federal ministers of intergovernmental affairs and Canadian Heritage and the provincial ministers responsible for francophone affairs (and intergovernmental affairs in Quebec). The Conference concerns itself with "all government activity relating to French-language services, official languages, and the Francophone and Acadian

\footnotetext{
${ }^{16}$ Fitzmaurice, supra, note 6 at 162.

${ }^{17}$ For additional information concerning this Senate Committee, please see http://parl.gc.ca/common/Committee_SenHome.

${ }^{18}$ Statute requires that 3 judges be from Quebec. However, the remainder of the court is appointed by "rough allocation", is a function of convention and may vary. Please see Hogg, supra, note 7 at Section 8.3 for a full discussion.
} 
communities."19 Also, the Council of Ministers of Education (CMEC) consists of the provincial ministers of education, and both consults intergovernmentally, and administers certain intergovernmental official languages programs and agreements. ${ }^{20}$

There are also informal institutions at work. While it is difficult to place a label on such informal structures, several authors cite their existence and influence. ${ }^{21}$ Moreover, the results of such informal relations are clear in the realm of both services and education. Relating to services, the federal government has entered into federalprovincial agreements to assist provincial governments provide services to official language minority communities. ${ }^{22}$ Relating to education, in addition to the "formal work” of the CMEC, the informal relations between governments have netted bilateral agreements to provide ad hoc support for special educational measures such as the establishment of post-secondary institutions. ${ }^{23}$

Given this background concerning federalism, it is now worthwhile to consider the background concerning policy outcomes.

\footnotetext{
${ }^{19}$ The purpose of this organization seems to be primarily to co-ordinate efforts and exchange information. For additional details, please see the organization's website, http://207.228.248.225/usrlib/afi/en/index.htm. Interestingly, not a single source researched for this paper referred to this organization.

${ }^{20}$ For example, the federal government and the provincial governments work through the CMEC on the "Official Languages in Education Program" which established a five year memorandum of understanding concerning the funding of minority-language education activities. See www.cmec.ca for complete information on the council. Interestingly, only a single source researched for this paper referred to this organization.

${ }^{21}$ For example, please see S. Churchill, New Canadian Perspectives: Official Languages in Canada: Changing the Language Landscape (Ottawa: Canadian Heritage, 1998) at 21and 24, and R. Schmidt, Sr. "The Politics of Language in Canada and the United States: Explaining the Differences" in T. Ricento \& B. Burnaby, eds., Language and Politics in the United States and Canada: Myths and Realities (Mahwah: Lawrence Erlbaum Associates, Publishers, 1998) at 50.

${ }^{22}$ For further information, please see the details provided by the Department of Canadian Heritage at http://www.canadianheritage.gc.ca/progs/lo-ol/progs/efpp-fpap_e.cfm. For example, the Canada-British Columbia Agreement, signed in April 2001, transfers \$1.5 million over three years to B.C. to allow it to provide additional support to its Francophone citizens. The full text of the agreement is available at http://www.gov.bc.ca/igrs/down/canada.pdf.

${ }^{23}$ Government of Canada, The Next Act: New Momentum for Canada's Linguistic Duality, the Action Plan for Official Languages (Ottawa: Privy Council Office, 2003) at Section 3.1.4.
} 


\section{Framework of Policy Outcomes}

Minority language rights could be defined broadly or narrowly. Given the comparative brevity of this paper, I have chosen a relatively narrow definition of minority language rights - namely, access to government services and instruction in (elementary and secondary) education in one’s language of birth. I review the content of language policies, by reference to these two indicators, for both of the Countries in the upcoming section.

\section{BELGIUM}

\section{GOVERNMENT SERVI CES}

The policy outcome concerning government services in Belgium is theoretically quite simple. In brief, Flanders and Walloon are officially unilingual language regions, functioning in Flemish and French respectively while the Brussels region is officially bilingual. The general rule for the national public service is bilingualism of service but unilingualism of employees. ${ }^{24}$ These policies were the result of essentially 2 waves of legislative reform. In the first wave of 1932 the general principles were established, whereas in the second wave of 1963, the enforcement of the principles was reinforced and certain loopholes were closed. ${ }^{25}$

\section{EDUCATI ON}

Similar to government services, in education, waves of reform resulted in a policy of unilingual instruction according to region. Specifically, according to the 1932 law, the language of instruction in Flanders, Walloon (and the German cantons) is the language of the region, whereas the language of instruction in Brussels is the child's mother tongue or

\footnotetext{
${ }^{24}$ McRae, supra, note 4 at 151 . It should be noted as well that the much smaller German speaking area in the Liege province (in Walloon) also functions unilingually. The German aspects to Belgian language policy are relatively insignificant and will not be pursued in this paper.

${ }^{25}$ McRae, supra, note 4 at 189-91.
} 
usual language. However, given some loopholes in the law of July 1932, allowing children to be educated in a language other than that of the region, following 1932, Flanders had a mostly Francophone system. ${ }^{26}$ Thus, the 1963 law was promulgated to apply the principles of the 1932 law more extensively and rigorously.

Essentially, in addition to affirming the two general principles of the 1932 reform, the 1963 law provided that minority education facilities at the elementary level would only be available, at a specific level of demand, for four groups of communes with minority language populations. Moreover, in order to qualify for "mother tongue” language of instruction, enrolment could only take place after a parental declaration of mother tongue which was then checked by a special linguistic inspectorate. ${ }^{27}$

This regime, dependent upon the language of the region, exists to date, although responsibility for education (and all matters concerning language) has since been devolved to the community level.

\section{CANADA}

\section{GOVERNMENT SERVI CES}

It is useful to review the language of government services in terms of federal and provincial services. In terms of federal services, the government's main commitments are set out in Section 20 of the C.A. 1982 and Section 2 of the Official Languages Act of $1969 .^{28}$ As described above, overall, the federal government has adopted a "panCanadian” approach and undertaken to provide services in either French or English, based on the citizen's choice, at any government head office, and at any other office, whenever it is either reasonable, or there is sufficient demand therefore.

\footnotetext{
${ }^{26} I d$., at 220 .

${ }^{27} I d$., at 221.

${ }^{28}$ Official Languages Act, 1968-69, R.S.C. 1970, c. O-2 (hereinafter OLA). The principles of the OLA were affirmed and added to in the Official Languages Act, R.S.C. 1985, c.31 ( $4^{\text {th }}$ supp.).
} 
In terms of provincial services, each province provides a different level of minority language service. The level of service provided in the minority language by each province is summarized in a table, attached at Appendix A. For the purposes of this discussion, it is useful to note that only New Brunswick offers all government services in both official languages. Some other provinces such as Ontario and Manitoba have designated "bilingual zones" where all government services are provided in either official language. Quebec on the other hand offers a variety of services in English, though does not have officially designated bilingual zones. Finally, certain provinces, such as Newfoundland and Saskatchewan offer only a telephone referral or translation service for their francophone populations.

\section{EDUCATI ON}

The obligation to provide minority language education is set out in Section 23 of the Charter. Quebec is exempt from Section 23(1)(a), although all the other provisions of Section 23 apply to Quebec, and the entire section applies to all the other provinces. Nonetheless, since Section 23 does not establish any absolute obligations, but rather one susceptible to interpretation, based on the "where numbers warrant" threshold, the provinces have provided varying levels of minority language access depending upon their numbers and their interpretation of their Section 23 obligations. The solution adopted by each province is summarized in the table at Appendix A. In brief, every province offers a different level of minority language instruction with, again, only New Brunswick offering equality of instruction between English and French, Ontario offering French language instruction regardless of a numbers threshold, and certain other provinces offering only scant minority language instruction. 
While it is difficult to assess whether this level of service satisfies Section 23, overall, S. Churchill notes that, as of 1998, 9 provinces had substantially implemented their Charter guarantees, with only British Columbia missing the mark. ${ }^{29}$ Although, given the lack of an absolute standard, existing efforts may not continue to meet constitutional scrutiny. In fact, recent S.C.C. cases have chastised provinces for failing to properly implement their Section 23 obligations. ${ }^{30}$ Thus overall, the level of minority language education across the provinces could be considered both inconsistent and evolving.

Against this background of both the federalist and the policy framework, it is appropriate to now discuss which factors caused minority language rights policies to develop as they did. I will begin this analysis with a discussion of the influence of the relative situation of language groups.

\section{PART II: DISCUSSION}

\section{A. Relative Situation of Language Groups}

\section{Numerical Importance Reflected In the Policy Outcome}

According to this argument, the relative situation of language groups can be asserted as a dominant influence on policy outcome because the numerical importance of the language group is so neatly reflected within the policy outcome itself. In other words, I can argue that the relative situation of the minority language group has causally affected policy

\footnotetext{
${ }^{29}$ Churchill, supra, note 21 at 32 .

${ }^{30}$ For example, in Arsenault-Cameron v. PEI [2000] 1 S.C.R. 3, the S.C.C. ordered PEI to provide a school for the Francophone children of Summerside, rather than just providing bus service to a school $28 \mathrm{~km}$ away. In a further example, in Doucet-Boudreau v. Nova Scotia (Minister of Education), 2003 SCC 62, the S.C.C. upheld a lower court's "Reporting Order" which required Nova Scotia and its school board to use their "best efforts" to provide Francophone school facilities and programs by particular dates and to report to the court on its progress, in response to a Section 23 violation. Similarly, an appeal is pending before the S.C.C. concerning Quebec's interpretation of Section 23. For a summary of that appeal, please see http://www.cbc.ca/stories/2004/03/22/canada/language_challenge040322.
} 
outcomes because the relative situation, assessed numerically, is so clearly projected within the terms of the policy.

This argument is purest in the Belgian example. In Belgium, language policy can be described as symmetric. The French and Flemish languages are treated equally, each with the exact same impact over the same level of population and territory. Interestingly, in keeping with the argument, Belgian society is also almost perfectly symmetric. According to A.B. Murphy, a "remarkable” feature of Belgium’s “linguistic geography” is its near perfect numerical and territorial parity between the French and the Flemish. In Murphy’s view, “there are few culturally or ethnically divided states that have as close a numerical balance between the major groups as does Belgium.”31 Similarly, according to the 1991 census figures, approximately 60\% of the Belgian population is Flemish speaking, while $40 \%$ is French speaking. ${ }^{32}$ Again, given this near-perfect distribution, symmetric policies appear to be in response to the symmetric break-down of the population. In this way, it can be asserted that policy outcomes in this sector have been causally influenced by the relative numerical situation of language groups in Belgian society.

In the Canadian example the policy outcomes do not reflect as neatly the numerical importance of language groups, though the causal effect of this variable is still clear by looking to the policy outcome's encapsulation of the general quantitative importance of the minority group. For example, at the provincial level, only one province, New Brunswick, grants parity to the two languages. While the Francophone minority does not represent a strict $50 \%$ of the New Brunswick population, it does

\footnotetext{
${ }^{31}$ A.B. Murphy, The Regional Dynamics of Language Differentiation in Belgium: A Study in CulturalPolitical Geography (Chicago: University of Chicago, 1988) at 4.

32 J.G. Prevost and J.P. Beaud, "Statistical Inquiry and the Management of Language Plurality in Canada, Belgium and Switzerland,” Journal of Canadian Studies Vol. 36, No. 4 (Winter 2002) pp. 88-117 at 96.
} 
represent approximately $35 \%$ of the population, more than any other language minority within a province and admittedly a significant proportion. ${ }^{33}$ Thus according to the argument, it is unsurprising that the minority language rights should be so generous. Moreover, after New Brunswick, the provinces with the next most significant official language minorities, Quebec (13\%) Ontario (5.0\%) and Manitoba (4.4\%) ${ }^{34}$ are also the provinces with the next most significant minority language rights. Finally, again consistent with the argument, the provinces with the least significant minority groups have the most restrictive minority language rights. For example Newfoundland, with its 0.4\% minority language population, offers only translation services to its Francophone minority rather than actual government services. Similarly, British Columbia, with its 1.5\% minority language population, was cited in the Churchill study as having failed to implement its Section 23 obligations. ${ }^{35}$

Thus, like in Belgium, at the provincial level in Canada, the content of policies reflect generally the numerical importance of the minority language group, with rights declining as numbers decline and vice versa. In this way, we can see that the relative status of the language groups has causally impacted policy outcomes

Admittedly, federal level policies are less consistent with this argument. The federal government has committed itself to pan-Canadian provision of minority language services, even though Francophones represent only approximately 25\% of the Canadian population. ${ }^{36}$ Thus, the two official languages are arguably treated equally, even though the relative groups are not equal in size. While this disparity between numerical importance and policy outcomes would superficially disprove the argument, I do not

\footnotetext{
${ }^{33}$ Statistics Canada, Canada Census, 1996

${ }^{34}$ Ibid.

${ }^{35}$ Ibid.

${ }^{36}$ J.E. Magnet, "Language Rights Theory in Canadian Perspective” in Ricento \& Burnaby, eds., supra, note 20 at 186.
} 
believe that the argument should be rejected on this basis. First, with its "numbers warrant" and "reasonable" thresholds, the actual practice, as opposed to the letter, of the policies has roughly adhered to the relative situation of language groups. For example, approximately $37 \%$ of positions in the federal public service are designated bilingual and approximately $31 \%$ of the public service was Francohpone in $2002 .^{37}$ While these figures do not illustrate exactly how many federal government services were provided in French as opposed to English, it does provide some insight into the break-down and suggests that, at most, approximately 35\% of federal government services were provided in French. This level of service is fairly consistent with the approximate numerical importance of the Francophone community in Canada.

Second, the relative situation of language groups extends beyond numerical importance and as the subsequent argument will detail. Francophones in Canada have enjoyed emerging relative importance in Canada (beyond their numbers), and this emerging importance helps further explain the content of the federal policy outcomes. I turn to this argument now.

\section{As the Relative Situation of Language Groups Change, so does the CONTENT OF THE POLICIES}

According to this argument, the influence of the relative situation of language groups on policy outcomes can be measured by observing how policy outcomes change in keeping with changes to the relative situation of language groups.

Belgium illustrates this argument well. In Belgium, Francophone Belgians typically dominated Belgian society and so did the French language. However, as the Flemings gained power (and the French lost power) Flemish earned parity with French. In greater detail, in 1830, Francophone Belgians dominated politics, education, economy

\footnotetext{
${ }^{37}$ Government of Canada, supra, note 23 at Section 5.1.3.
} 
and society and accordingly, French was the state language. ${ }^{38}$ However, by 1963, Flemish was firmly entrenched as equal to French. In my view, this change can be accounted for by adjustments in relative position between the French and the Flemings.

On the demographic level, following World War II, the Flemings grew in importance relative to their French compatriots. Specifically, between 1948 and 1980, Flanders outgrew Walloon, with the population of Flanders growing by $24.1 \%$ and the population of Walloon by only $8.2 \%{ }^{39}$ The importance of this numerical shift is discussed above.

However, beyond a demographic shift, over time, an important economic shift took place to the advantage of Flanders and the disadvantage of Walloon. Beginning with Independence, though most rapidly following WWII, the economic centre of Belgium moved from Walloon to Flanders. Specifically, Belgian's first wave of industrialization took place in Walloon, with its important steel and coal industries. However, following WWII, the coal and steel industry, and therefore Walloon's economic fortunes, declined, while Flanders, with its "new industries" of electronics, petrochemicals, highly skilled labour, foreign investment and diversification, flourished. ${ }^{40}$ In output terms, overall, between 1955 and 1960, Flanders GDP grew by $16.5 \%$ while Walloon’s GDP grew by only 5.5\%. Moreover, per capita income in Flanders overtook per capita income in Walloon in $1966 .{ }^{41}$

\footnotetext{
${ }^{38}$ M. Covell, "Minority Language Policy in Canada and Europe: Does Federalism Make a Difference?” in H. Bakvis \& G. Skogstad, eds., Canadian Federalism: Performance, Effectiveness, and Legitimacy (Don Mills: Oxford University Press, 2002) at 249 and P. Kurzer, "Decline or Preservation of Executive Capacity? Political and Economic Integration Revisited,” Journal of Common Market Studies Vol. 35, No. 1 (March 1997) pp. 31-56 at 36.

${ }^{39}$ McRae, supra, note 4 at 48.

${ }^{40}$ J. Fitzmaurice, The Politics of Belgium: Crisis \& Compromise in a Plural Society (London: C. Hurst \& Company, 1988) at 62

${ }^{41}$ Ibid.
} 
Language policy captured the impact of this shift in economic fortunes. Specifically, bolstered by their new relative strength, the Flemish demanded redress on the language front. According to P. Kurzer, Flemish leaders, “emboldened” by their transformation, began demanding state reforms and began to challenge the "persistent primacy” of French in higher education, state bureaucracies and Brussels. ${ }^{42} \mathrm{~J}$. Fitzmaurice describes it as the Flemish movement demanding from the French speaking state "consideration commensurate to its size and economic power." 43

While the Flemings sought and achieved linguistic parity with the French, it is interesting that given their demographic and economic ascendance, they did not seek more than parity. In my view, this is because the French were able to remain superior to the Flemings in terms of the last category of relative situation, social situation. Because of this, the French were able to "balance" the language demands of the Flemings.

Specifically, French has a privileged status in Belgian society. According to K.D. McRae, French is considered prestigious: Flemish parents believe that bilingual education is necessary for their children's upward mobility, and the French cling to a feeling of superiority which is undisputed by the Flemish. ${ }^{44}$ Thus relatively speaking, the French have a better social situation than the Flemings and this appears to have influenced their ability to claim language parity.

Overall, these complicated demographic, economic and social adjustments in relative situation between the French and the Flemish in Belgium are clearly reflected in language policies. In essence, the Flemings have achieved language parity in keeping with their numerical and economic growth, while the French have protected language parity despite their relative decline, though commensurate with social status.

\footnotetext{
${ }^{42}$ Kurzer, supra, note 38 at 39.

${ }^{43}$ Fitzmaurice, supra, note 6 at 267.

${ }^{44}$ McRae, supra, note 4 at 94, 314 and 325.
} 
In Canada it is also possible to measure the impact of the relative situation of language groups on policy outcomes by observing how policies changed as the relative situation of language groups changed.

As detailed above, Canada's language policies underwent important changes from the late 1960's through to 1982. As a result of these changes, French moved from being marginalized, to being equal at the federal level, supreme in Quebec, and increasingly important in some other provinces as well. Again, in my view, a dominant influence over this evolution in policy is the relative situation of language groups.

Generally speaking, until the 1960s, Francophones in Canada played a secondary role in society. ${ }^{45}$ However, beginning with the Quiet Revolution, Francophones in Quebec, and even outside Quebec began to climb in importance. According to Churchill, with the Quiet Revolution, French speaking Quebeckers:

...shook off the traditions of a clerically-dominated civil, mainly rural society, modernized the structures of the provincial government, expanded massively the public education system, founded a host of post-secondary institutions serving French speakers and expanded their control of the private sector economy. ${ }^{46}$

Many authors comment on how this Francophone emergence affected the policy landscape throughout Canada. In terms of its effect on Quebec language legislation, according to C.M. MacMillan, Bill 101 (the Charter of French Language) was “an important symbolic gesture" emphasizing the quality and influence of the French language in Quebec life and an effort to assert Quebecois personality "in all aspects of Quebec life.”47 In M. Covell’s view, in Quebec, "the economically disadvantaged and culturally threatened French linguistic community mobilized politically and used the state

\footnotetext{
${ }^{45}$ Covell, supra, note 38 at 243.

${ }^{46}$ Churchill, supra, note 21 at 14 . Please also see Schmidt, supra, note 21 at 65.

${ }^{47}$ C.M. MacMillan, The Practice of Language Rights in Canada (Toronto: University of Toronto Press, 1998) at 101.
} 
to secure its culture and redistribute group power in its favour." ${ }^{48}$ Finally, according to T. Ricento, language planning in Quebec was used to overcome lingering resentment relating to [past] socioeconomic subordination. ${ }^{49}$ Thus clearly, in the Quebec context, as French power grew, so did French language rights.

In terms of the effect of the emerging Francohpone movement on federal legislation, the federal regime responded by introducing a new language regime. More exactly, certain authors describe the OLA as the federal government's response to the Quiet Revolution. ${ }^{50}$ Precisely, the Royal Commission on Bilingualism and Biculturalism ( $B \& B$ Commission) was appointed by the federal government to respond to the "new force of Quebec's nationalism” in Canadian public life. The Commission was charged with finding a more "modern" solution to the enduring difficulties between French and English language groups in Canada. ${ }^{51}$ Of course it was the $B \& B$ Commission which recommended the OLA provisions concerning equality between the two languages. So in this indirect way, "French power” engendered an entirely new federal language regime.

At the provincial level (outside Quebec), the effects of the changing situation of language groups on policy can be observed as well. For example, the emergence of Francophone "power" prompted all of the provinces to take some action to extend their minority language services. For example, in 1977 (following the 1976 Parti Quebecois election) the nine (non-Quebec) premiers adopted a declaration agreeing that they would "make their best efforts to provide instruction in English and French [to official language minorities] wherever numbers warrant.,52

\footnotetext{
${ }^{48}$ Covell, supra, note 38 at 252.

${ }^{49}$ T. Ricento, "Partitioning by Language: Whose Rights are Threatened?” in Ricento \& Burnaby, eds., supra note 21 at 320-1.

${ }^{50}$ Schmidt, supra, note 21 at 40.

${ }^{51} \mathrm{Id}$., at 47

${ }^{52}$ Churchill, supra, note 21 at 22.
} 
Apparently, though, only the provinces which were internally struck by the changing balance between Francophones and Anglophones actually instituted any considerable policy changes. For example, certain authors cite that at the same time as the Quiet Revolution, Francophone minorities in New Brunswick and Ontario also began to assert themselves. ${ }^{53}$ Not surprisingly, these provinces were the only ones who undertook meaningful policy extensions to Francophone minorities. For example, in 1970, Ontario gave official status to French in the Legislature, and between 1979 and 1986, French was extended to become an official language of the entire provincial court system for criminal matters. ${ }^{54}$ Thus consistent with the argument, in those provinces with a changing situation between language groups, policy changes came about in reaction to that changing situation. However, in those provinces without any emerging Francophone power, there was also no corresponding change in policy.

While the relative situation of language groups explains to a meaningful degree the policy outcomes in this sector, it does not explain all. In order to shed further light on the "causes" of the content of minority language rights policies I turn now to consider the influence of political culture.

\section{B. Political Values and Culture}

For this discussion, I propose two arguments in support of the dominant causal influence of political culture on policy outcomes in this sector. First, I argue that the causal influence of political culture can be asserted based on how clearly the political values are reflected within policy outcomes; and second, I argue that the influence of political culture can be measured by observing how policy outcomes shift to respond to threats to political values.

\footnotetext{
53 Id., at 14; Covell, supra, note 38 at 243; Prevost \& Beaud, supra, note 32 at 106.

${ }^{54}$ Churchill, supra, note 21 at 39.
} 


\section{Political Values are Reflected in the Policy Outcomes}

Belgium has always officially extolled its commitment to equality between French and Flemish and this commitment, and the response thereto, has been neatly reflected in policies. In terms of a commitment to equality, as McRae points out, in Belgium:

...every question on the political agenda has been scrutinized closely from a linguistic and regional standpoint, and appropriate balances have been sought....political tendency ...to demand an equilibrium between Flanders and Wallonie in all policy decisions. ${ }^{55}$

M. Jaumain also comments on the enduring commitment to equality in Belgian society. Jaumain notes that there are several pillars in Belgian society and that each pillar works to reach agreements that reflect the proportional influence of each group. ${ }^{56}$

This commitment to equality has been clearly integrated into language policies. McRae calls the "absolute equality of the two official languages" one of the four principles of Belgian language legislation. ${ }^{57}$ While not repeated here, as described above, French and Flemish are treated equally by statute and by the constitution.

It is not universally accepted, however, that a commitment to equality is part of Belgium's political belief system. For example, Murphy argues that it is not a commitment to equality which motivates Belgian society, but rather, what motivates is the "double minority complex" and a desire within the two groups to be separate and apart. According to Murphy, the Flemings have minority feelings because of their traditional linguistic disadvantage and economic stagnation while the Walloons began to suffer from minoritization in the 1960s due to their economic and demographic decline, which began following WWII. ${ }^{58}$

\footnotetext{
${ }^{55}$ McRae, supra, note 4 at 116.

${ }^{56}$ Jaumain, supra, note 2 at 207.

${ }^{57}$ McRae, supra, note 4 at 151 . The other 3 principles are: Flanders and Wallonie are officially unilingual language regions; the national public service is bilingual in service but unilingual in employees and Brussels is officially bilingual.

${ }^{58}$ Murphy, supra, note 31 at 141.
} 
Policy outcomes do possibly reflect this double-minority complex. Fitzmaurice describes the effect of the complex as follows: In reaction to the Flemish nationalist movement, the Walloon movement developed, and the two communities then turned inwards towards themselves, seeking autonomy in cultural and economic policy areas. ${ }^{59}$ Murphy completes the thought and argues that in terms of policy outcomes, because of the double minority complex, language became organized along ethno(-regional) lines so that each language group could avoid feeling dominated by the other. ${ }^{60}$

I am not prepared to resolve this debate today, and conclude whether it was indeed the quest for equality or the double-minority complex which is in fact reflected within Belgium's existing language regime. However, it is worthwhile to note the debate and note that regardless of which aspect of political culture motivated the content of the policy, it was clearly political culture (however you circumscribe it) which influenced policy outcomes and which is encapsulated therein.

The commitment to equality is equally promoted as a Canadian political value, although in Canada, like in Belgium, there is some debate as to what equality means in this policy context. The policy outcomes capture the equivocating tone of the debate over the content of the political value.

Equality between French and English at the national level is widely accepted. The $B \& B$ Commission took as its guiding principle the equal partnership of the two linguistic communities ${ }^{61}$ and wrote, "the proper goal for Canada is an equal partnership not only of the two people who founded Confederation but also of each of their respective languages

\footnotetext{
${ }^{59}$ Fitzmaurice, supra, note 6 at 78.

${ }^{60}$ Murphy, supra, note 31 at $131-2$ and 141.

${ }^{61}$ MacMillan, supra, note 47 at 71.
} 
and cultures.”62 Academics agree with this conception of Canadian political culture. As J.E. Magnet describes it, Canada "formed out of two nations as a binational state. Binationality (duality) is a fundamental inspiration of Canada’s system of governance.”63

This commitment to equality is clearly enshrined within federal language policies. Both the OLA and the Charter advocate that French and English are equal within Canada and attempt to create a framework of equal status and equal treatment for English and French speakers. ${ }^{64}$ As Magnet writes:

Canadian language rights strive to create fair processes for the participation of both communities in the machinery of government, and attempt to moderate the effects of linguistic differences in the operation of the governmental machine. ${ }^{65}$

If this commitment to equality is part of the Canadian political value system, what explains certain provinces' reluctance to implement equal policies for the two language groups at the provincial level? MacMillan explains the variation by arguing that support for rights is uneven, and that studies indicate that support for provincial language rights changes according to region and according to the language right at stake. However, the same studies illustrate that Canadians consistently believe that it is the federal government's role to protect official language minorities and to promote both official languages. ${ }^{66}$ Against this inconsistency, MacMillan concludes that:

...the present array of language policy commitments, consisting of a short list of constitutionally entrenched language rights applicable to only the federal government and New Brunswick, national commitments to minority language education....and freedom for the remaining provinces is closely attuned to the public predisposition in these matters... ${ }^{67}$

\footnotetext{
${ }^{62}$ Royal Commission on Bilingualism and Biculturalism. (1967) Report (Vol. I) Ottawa: Queen’s Printer at 4-5.

${ }^{63}$ Magnet, supra, note 36 at 199.

${ }^{64}$ Churchill, supra, note 21 at 18.

65 Magnet, supra, note 36 at 188.

${ }^{66}$ MacMillan, supra, note 47 at 39-43 and Churchill, supra, note 21 at 54.

${ }^{67}$ MacMillan, supra, note 47 at 228.
} 
In other words, there is an unwavering commitment to equality at the federal level, though a wavering commitment to equality at the provincial level. This fluctuating interpretation of the political value of equality is clearly reflected in policy outcomes.

The influential role of political culture can also be measured by observing how policies change in defense of threatened political values. I turn to this argument next.

\section{As Political Values are Threatened, Policy Outcomes will Change to PROTECT THOSE VALUES}

According to this argument, one can measure the influence of political culture by observing how the policy outcomes change to protect the political value, as the political value is threatened.

This argument is well-illustrated in the Belgian example. In Belgium, as described above, there is a commitment to equality, but there has also been a reconfiguration of relative power in favour of the Flemings. This rebalance between Fleming and French has contributed to the "downgrading" of the idea of "Belgian-ness" in favour of regional-linguistic association, ${ }^{68}$ which can of course be perceived as a "threat" to the commitment to equality. Arguably, it is difficult to preserve the value of equality against this threat, but language policy has responded with some protective measures. Specifically, as the commitment to equality was threatened by the evolving Flemish movement and Walloon response thereto, equality was continually reinforced. For example, during the 1970 constitutional amendments, article 86 was promulgated to guarantee parity between French and Flemish speakers in the national cabinet. Further, the language laws of 1963 reinforced the rule that national public services are bilingual but employees are unilingual. This formula was apparently adopted to protect the

\footnotetext{
${ }^{68}$ M. O’Neill, “Belgium: Language, Ethnicity and Nationality,” Parliamentary Affairs Vol. 53, No. 1 (January 2000) pp. 114-134 at 117.
} 
equality of Walloons within the public service. ${ }^{69}$ Thus, while Belgian society has undergone some fundamental changes which challenge the commitment to equality, language policy has responded by protecting equality, rather than discounting it.

In Canada the dominant influence of political culture can also be gauged by considering how policy outcomes have evolved in response to threats to the equality guarantee. The argument in the Canadian context is best illustrated by reviewing the evolution of language laws in Quebec. Specifically, in Quebec, it is compellingly argued that the province's language regime, which promotes French and demotes English, was actually prompted by the threat to equality created by the federal government's inadequate language policies.

In greater detail, as described above, the $B \& B$ Commission enunciated a commitment to equality between French and English speakers in Canada, and recommended a language regime which allowed either Anglophone or Francophone Canadians to "feel at home", anywhere in the country. ${ }^{70}$ In Quebec's view, this panCanadian approach was inadequate to protect French and promote it to a position of equivalence with English in Canada. Instead, as Schmidt argues, Quebec believed that in order to establish equality in a bilingual country, against the tide of English, Quebec needed to be unilingually French. In Schmidt's words:

Quebec's rationale for Bill 101's illiberal policy of restrictiveness was based on its understanding of the seriousness of the linguistic and cultural crisis faced by francophones in overwhelmingly anglophone North America....Because inequality between the two language groups was a fact of life from the time of the Conquest, there were reasons to believe that the individualistic premises of the liberal pluralist policy of the federal government would not succeed in protecting the survival of the Quebecois language and culture, much less ensure their elevation to the position of equality. ${ }^{71}$

\footnotetext{
${ }^{69}$ McRae, supra, note 4 at 151.

${ }^{70}$ R. Beaujot, "Demographic Considerations in Canadian Language Policy” in Ricento \& Burnaby, eds., supra, note 21 at 81.

${ }^{71}$ Schmidt, supra, note 21 at 54 . Emphasis added.
} 
Thus, according to this argument, in order to promote equality, in response to the threat thereto posed by the federal government, Quebec adopted its essentially unilingual French language regime.

One may wonder, though, whether this argument is too facile and dismissive of the influence of nationalism? Moreover, does it mis-label as "protection of equality” what is just Quebec’s rejection of the Canadian national project? I submit not. While nationalism clearly has its own independent causal impact on outcomes in this policy sector, ${ }^{72}$ I do not believe that it is astute to reject the argument that Quebec's policy choices were responding to a threat to equality.

Quebec has always sought equality for the French language within Canada and has genuinely perceived that its language laws are promulgated in order to overcome barriers to that equality. As Premier Jean Lesage stated in a 1965 speech, “Quebec, as the cornerstone of French Canada, is asking for the equality of Canada's two founding ethnic groups. It is seeking a status that respects its special characteristics.”73 ${ }^{\text {Moreover, }}$ Quebec has consistently rejected the separatist option, and has participated in further constitutional negotiations. During each round of negotiations, Quebec has argued in favour of promoting French within Quebec and the rest of Canada, ${ }^{74}$ bolstering the initial argument that Quebec was motivated by threats to equality, rather than just brute nationalism, when designing its language laws. Once again, I am not in a position in this paper to conclusively resolve which aspect of political culture affected the content of minority language rights but only to assert that it was indeed political culture which

\footnotetext{
${ }^{72}$ Please see Footnote 1.

${ }^{73}$ Magnet, supra, note 36 at 200.

${ }^{74}$ For a summary of the language provisions of both the Meech and Charlottetown constitutional negotiations, please see Magnet, supra, note 36 at 200-1.
} 
played a dominant causal role. In my view, the above discussion achieves this modest goal.

\section{CONCLUSION}

In this paper I set out to determine what factors causally affected the content of minority language rights policies in the Countries. I argued that two factors primarily influenced policy outcomes: relative situation of language groups and political culture. By reviewing both how these Dominant Variables were integrated into policy outcomes and how policy outcomes shifted along with shifts in the Dominant Variables, I was able to ground my arguments. But my discussion, as successful as it was, also left certain important questions unanswered.

First, as I outlined in my introduction, outcomes in this policy sector are more responsive to normative variables than institutional ones. But, will this dichotomy hold, or, will institutional variables begin to assert more influence over policy outcomes? For example, will tensions between language groups in Belgium reach a level such that the alarm-bell procedure is invoked to change the trajectory of a language initiative; or, will the $C M E C$ become an organization of force, and co-operate with the federal government to institute genuine policy change respecting French language instruction in Canada? Only continued observation of this policy sector can answer these questions.

Second, even if the Dominant Variables continue to hold sway over policy outcomes in this sector, will they engender policy outcomes in line with past outcomes, or will they engender different policy outcomes? For example, will the double-minority complex in Belgium become so deeply entrenched that the current language laws are irrelevant and Belgians begin to question the purpose of the federation? Or, will the relative situation of the Francophone minority outside Quebec become so weak that it 
loses its claim to language rights and the commitment to equality becomes absurd? These and other questions will also likely arise in the future; and again, it will be useful to continue to monitor this policy sector to observe how and if the Dominant Variables influence policy outcomes in the future.

Third, I found that IGR did not make a significant difference to policy outcomes in the minority language rights sector. Why? Perhaps it is because the arena of minority language rights is so politically charged that institutionalizing the debate would create nothing but additional conflict. However, certain authors disagree and suggest that institutionalizing the arena would not create conflict, but rather, would channel and resolve the debate, converting it from a sensitive topic to a manageable dialogue. ${ }^{75}$ Since my paper focused on what factors did make a difference, I did not explore this discussion. As a student of IGR, though, I can not resist flagging it and identifying it as a topic of curiosity and interest. I therefore conclude with a short warning: perhaps a future paper will consider not what does matter to minority language rights, but why IGR does not!

\footnotetext{
${ }^{75}$ McRae, supra, note 4 at 4; Magnet, supra, note 62 at 194.
} 


\begin{tabular}{|c|c|c|c|c|c|}
\hline PROVI NCE & $\begin{array}{l}\text { OFFI CI AL } \\
\text { LANGUAGE }\end{array}$ & $\begin{array}{l}\text { OFFICI AL } \\
\text { LANGUAGE } \\
\text { MINORITIES } \\
\text { (NUMBERS } \\
\text { AND \%) }\end{array}$ & $\begin{array}{l}\text { LANGUAGE OF } \\
\text { GOVERNMENT SERVI CES }\end{array}$ & $\begin{array}{l}\text { LANGUAGE OF } \\
\text { INSTRUCTI ON IN } \\
\text { EDUCATION }\end{array}$ & SOURCE \\
\hline Alberta & & $\begin{array}{l}52,500 \\
2.0\end{array}$ & $\begin{array}{l}\text { No provincial policy or } \\
\text { legislation on services in } \\
\text { French. } \\
\text { In practice, services may be } \\
\text { provided on a "case-by-case" } \\
\text { basis. }\end{array}$ & $\begin{array}{l}\text { Right of official language } \\
\text { minority to instruction in French } \\
\text { where the number is "sufficient" } \\
17 \text { French-language schools. }\end{array}$ & $\begin{array}{l}\text { http://207.228.248.225/usrlib/a } \\
\text { fi/profils/Profil\%20AB\%202002 } \\
\text {-E.doc } \\
\text { Phone conversation with } \\
\text { official Denis Tardif, Director } \\
\text { Francophone Directorate, on } \\
\text { April 5, } 2004 \text {. }\end{array}$ \\
\hline $\begin{array}{l}\text { British } \\
\text { Columbia }\end{array}$ & & $\begin{array}{l}56,310 \\
1.5\end{array}$ & $\begin{array}{l}\text { No provincial legislation or } \\
\text { policy on the provision of } \\
\text { services in French. } \\
\text { Enquiry BC Call Centre } \\
\text { provides multilingual service to } \\
\text { all B.C. citizens on behalf of all } \\
\text { ministries, crown corporations } \\
\text { and public agencies, including } \\
\text { in French. } \\
\text { Some ministries are able to } \\
\text { provide limited ad hoc services } \\
\text { in French. } \\
\text { The office of the manager, } \\
\text { Canada-B.C. Agreement on } \\
\text { Official Languages, offers } \\
\text { minimal translation services to } \\
\text { other government ministries and } \\
\text { administers translation of other } \\
\text { key documents identified by the } \\
\text { francophone community. }\end{array}$ & $\begin{array}{l}\text { Parents who qualify under s. } 23 \\
\text { can send their children to } \\
\text { French language schools. } \\
\text { A Francophone Education } \\
\text { Authority was created in } 1995 \text {. } \\
\text { In the } 2001 / 2002 \text { school year, } \\
\text { there were } 2873 \text { students } \\
\text { registered in the Francophone } \\
\text { program ( } 2325 \text { in elementary, } \\
548 \text { in secondary) administered } \\
\text { by Conseil scolaire francophone } \\
\text { de la C.-B. (CSF). The CSF is } \\
\text { offering its program in } 40 \\
\text { schools throughout the } \\
\text { province. }\end{array}$ & $\begin{array}{l}\text { http://207.228.248.225/usrlib/a } \\
\text { fi/profils/Profil\%20CB\%202002 } \\
\text { \%20-\%20E.doc }\end{array}$ \\
\hline Manitoba & English & $\begin{array}{l}46,570 \\
4.4\end{array}$ & $\begin{array}{l}\text { Manitoba provides bilingual } \\
\text { government services in } 6 \\
\text { designated areas of the } \\
\text { province. }\end{array}$ & $\begin{array}{l}\text { Parents who qualify under s. } 23 \\
\text { can send their children to } \\
\text { French language schools. } \\
\text { French language schools are } \\
\text { offered through "Division } \\
\text { Scolaire Franco-Manitobaine". } \\
\text { The DSFM has approximately } \\
4500 \text { students and } 22 \text { schools } \\
\text { in Manitoba. }\end{array}$ & $\begin{array}{l}\text { http://www.gov.mb.ca/fls- } \\
\text { slf/index.fr.html } \\
\text { http://www.edu.gov.mb.ca/ms4 } \\
\text { /progetu/prog-fr.html } \\
\text { http://207.228.248.225/usrlib/a } \\
\text { fi/profils/Profil\%20MB\%202002 } \\
\text {-E.doc } \\
\text { E-mails with provincial officials } \\
\text { Paule Buours from the Ministry } \\
\text { of Education and Angele } \\
\text { Saaghy from the French } \\
\text { Language Services Secretariat } \\
\text { on March } 26 \text { and } 30,2004 \text {. }\end{array}$ \\
\hline New Brunswick & French/English & $\begin{array}{l}241,040 \\
33.0 \% \text { (French } \\
\text { minority) }\end{array}$ & $\begin{array}{l}\text { New Brunswick provides } \\
\text { services to the public in both } \\
\text { official languages. } \\
\text { Where services are offered to } \\
\text { the public, there is a } \\
\text { constitutional obligation to } \\
\text { provide such services in the } \\
\text { official language of choice. } \\
\text { There are no exceptions based } \\
\text { on the existence of minimum } \\
\text { numbers of either linguistic } \\
\text { community in a particular area. }\end{array}$ & $\begin{array}{l}\text { New Brunswick guarantees } \\
\text { each education either official } \\
\text { Language. Parents are able to } \\
\text { send their children either to } \\
\text { Francophone or Anglophone } \\
\text { schools so long as the child is } \\
\text { able to function in the language } \\
\text { of instruction of the school. } \\
\text { The school system has two } \\
\text { parallel structures, one in } \\
\text { English and one in French. } \\
\text { There are } 107 \text { French language } \\
\text { elementary and high schools. }\end{array}$ & $\begin{array}{l}\text { http://www.gnb.ca/0163/ool- } \\
\text { blo/policy-e.asp } \\
\text { http://207.228.248.225/usrlib/a } \\
\text { fi/profils/Profil\%20NB\%202002 } \\
\text {-E.doc } \\
\text { E -mail correspondence with } \\
\text { provincial government official } \\
\text { Barry Lyndon from the Ministry } \\
\text { of Education on March 25, } \\
2004 \text {. }\end{array}$ \\
\hline Newfoundland & English & $\begin{array}{l}2270 \\
0.4 \%\end{array}$ & $\begin{array}{l}\text { There is no policy or law in } \\
\text { Newfoundland and Labrador } \\
\text { regarding the provision of } \\
\text { provincial government services } \\
\text { in French. }\end{array}$ & $\begin{array}{l}\text { Parents who qualify under s. } 23 \\
\text { can send their children to } \\
\text { French language schools. } \\
\text { There are currently } 5 \text { French } \\
\text { language schools in }\end{array}$ & $\begin{array}{l}\text { http://www.gov.nf.ca/frenchser } \\
\text { vices/default.htm } \\
\text { http://207.228.248.225/usrlib/a } \\
\text { fi/profils/Profil\%20TN\&L\%2020 } \\
\text { 02-E.doc }\end{array}$ \\
\hline
\end{tabular}




\section{Articles}

M. Jaumain, "Some Features of Cultural Policies Applied in Belgium, Particularly in the French-Speaking Community,” Journal of Arts Management, Law, and Society Vol. 27, No. 3 (Fall 1997) pp. 205-225.

P. Kurzer, "Decline or Preservation of Executive Capacity? Political and Economic Integration Revisited,” Journal of Common Market Studies Vol. 35, No. 1 (March 1997) pp. 31-56.

M. O’Neill, “Belgium: Language, Ethnicity and Nationality,” Parliamentary Affairs Vol. 53, No. 1 (January 2000) pp. 114-134.

J.G. Prevost and J.P. Beaud, "Statistical Inquiry and the Management of Language Plurality in Canada, Belgium and Switzerland,” Journal of Canadian Studies Vol. 36, No. 4 (Winter 2002) pp. 88-117.

W. Swenden, “Asymmetric Federalism and Coalition-Making in Belgium,” Publius Vol. 32, No. 3 (Summer 2002) pp. 67-87.

\section{Books}

H. Bakvis \& G. Skogstad. Canadian Federalism: Performance, Effectiveness, and Legitimacy. (Don Mills: Oxford University Press, 2002).

J. Fitzmaurice. The Politics of Belgium: Crisis and Compromise in a Plural Society. (London: C. Hurst \& Company, 1988).

—, The Politics of Belgium: A Unique Federalism. (London: Westview Press, 1996).

P.W. Hogg. Constitutional Law of Canada, vols. 1\&2, $4^{\text {th }}$ ed. (loose leaf) (Scarborough: Carswell, 1997-).

C.M. MacMillan. The Practice of Language Rights in Canada. (Toronto: University of Toronto Press, 1998).

K.D. McRae. Conflict and Compromise in Multilingual Societies. (Belgium) (Waterloo: Wilfred Laurier Press, 1986).

A.B. Murphy, The Regional Dynamics of Language Differentiation in Belgium: A Study in Cultural-Political Geography. (Chicago: University of Chicago, 1988)

T. Ricento \& B. Burnaby, eds.. Language and Politics in the United States and Canada: Myths and Realities. (Mahway: Lawrence Erlbaum Associates, Publishers, 1998) 


\section{Government Publications}

S. Churchill. New Canadian Perspectives: Official Languages in Canada: Changing the Language Landscape. (Ottawa: Canadian Heritage, 1998).

Government of Canada. The Next Act: New Momentum for Canada's Linguistic Duality, the Action Plan for Official Languages. (Ottawa: Privy Council Office, 2003). 